褐変 Glucosamine のラット血清脂質 及び肝臟脂質の脂肪酸組成に与える

$$
\text { 影響について }
$$

小柳津周* ・ 田村 弘**

Effects of Free Glucosamine and its Browning Products on Fatty Acid Compositions of Serum and Liver Lipids in Rats

Makoto Oyaizu* and Hiroshi Tamura **

${ }^{*}$ Musashino Nutrition College, 3-12-5, Minami Ikebukuro, Toshima-ku, Tokyo 171

* Experimental Animal Center, School of Medicine, Teikyo University, 2-11-1, Kaga, Itabashi-ku, Tokyo 173

In the previous paper, we reported that browning products of glucosamine (BGA) lowered the proportion of the total polyenoic acids in total lipids of serum and liver of rats. In this paper, the fatty acid composition of serum and liver lipid classes in rats administered free glucosamine (FGA) and BGA were examined by means of thin layer chromatography (TLC) and gas liquid chromatography (GLC). The results obtained were as follows; (1) Serum and liver lipid could be separated into seven classes (sterol esters, triacylglycerines, free fatty acids, 1.2-, 1.3-diacylglycerines, sterols and compound lipids). (2) Fifteen to twenty fatty acids were found in the serum and liver lipid; the major fatty acids were $\mathrm{C} 16: 0$, $\mathrm{C} 18: 0, \mathrm{C} 18: 1, \mathrm{C} 18: 2$ and $\mathrm{C} 20: 4$. (3) Total polyenoic acid content in serum of the rats administered FGA was higher than that of the animals administered BGA.

(Received Sep. 5, 1989)

著者らは，すでに Glucosamine 及びその褐変物質 の抗酸化性 ${ }^{1) \sim 4)}$ ，さらにそれらを投与したラット血清中 の T-Chol 及び TG 量の増加抑制傾向ならびに BGA の脂肪酸に与える影響を認めている ${ }^{5)}$.

そこで，ラットについてさらに詳しくFGA 及び
BGA が血清及び肝臓総脂質の脂質組成や各脂質の脂肪 酸組成に与える影響を検討した.

1. 供試動物及び実験方法

1. 飼育条件及び総脂質の抽出

供試動物，飼料配合割合，摂餌量及び投与期間につい ては前報りの条件に従った。 さらに，FGA，BGA 及び グルコサミン塩酸塩 $(\mathrm{GA}-\mathrm{HCl}$ ) の性状と血清及び肝 臓加ら総脂質 (TL) の抽出は前報)之同様に行った.

2. 血清, 肝臓 TL の脂質組成及び各脂質の脂肪酸 組成

薄層クロマトグラフィー（以下，TLC）による TL の分画は，和田ら ${ }^{6)}$ 及び山田ら ${ }^{7)}$ の方法により行った。 さらに同定は，標準脂質との $\mathrm{Rf}$ 值の比較により行った.

また，血清及び肝臓の各脂質の脂肪酸の分析は，日立 163 型ガスクロマトグラフィー（GLC）により前報5) 同様に行った。

\section{2. 結果及ひ考察}

1. 血清及び肝腀の脂質組成

血清及び肝臟 TL にっいて（TLC 分画により）ステ ロールエステル（以下，SE），トリアシルグリセリド (以下, TG), 遊離脂肪酸 (以下, FFA), ステロール (以下, ST), 複合脂質 (以下, CL), 1.2-, 1.3-ジア シルグリセリドの 7 種を検出した．各群の血清及び肝臟 の脂質組成には逵いがなかった，また，TG が最も多い と推定された.

\section{2. 血清及び肝臟の各脂質の脂肪酸組成}

各血清及び肝臟 TL の上記 7 画分のうち, SE, TG, FFA，CL の脂肪酸組成を Table 1 と 2 に示した.

血清中の各脂質の脂肪酸は，15 17 種類を認め，そ の主要脂肪酸は, C $16: 0, \mathrm{C} 18: 0, \mathrm{C} 18: 1$, C $18: 2$, $\mathrm{C} 20: 4$ でありC $18: 1, \mathrm{C} 18: 2$ が全脂肪酸の 40 50 \%を占めた ${ }^{8)}$ ままた， CL，TG，FFA の総飽和脂肪酸， モノェン酸, ポリェン酸量を Fig. 1 に示した. 各群間 で総飽和酸，モノエン酸、ポリエン酸量に差が認められ た.

すなわち，CL のモノエン酸量は, Control $>\mathrm{BGA}$ $>\mathrm{GA}-\mathrm{HCl}>\mathrm{FGA}$ の順で多く、ポリエン酸量は, FGA $>$ BGA $>$ GA-HCI $>$ Control の順であった. TG のモノェン酸量は, $\mathrm{GA}-\mathrm{HCl}>\mathrm{FGA}>$ Control $>$ $\mathrm{BGA}$ の順であり，ポリエン酸量は, $\mathrm{FGA}>\mathrm{GA}-\mathrm{HCl}$ $>$ BGA > Control の順であった. FFA のモノェン酸 量は，BGA > GA- $\mathrm{HCl}>$ Control $>$ FGA の順であり,

*武蔵野栄養専門学校（宁171 東京都豊島区南池袋 3-12-5）

** 帝京大学医学部（广173 東京都板橋区加賀 2-11-1） 
Table 1 Composition of main fatty acids of serum lipid in the rats

(wt\%)

\begin{tabular}{|c|c|c|c|c|c|}
\hline $\begin{array}{l}\text { Fatty } \\
\text { acids }\end{array}$ & DG* & Sterol esters & Triacylglycerines & Free fatty acids & Compound lipids \\
\hline \multirow[t]{4}{*}{$\mathrm{C} 14: 0$} & $\mathrm{C}$ & $6.23 \pm 1.3^{b}$ & $3.78 \pm 0.5^{* *}$ & $4.57 \pm 1.0$ & $5.34 \pm 0.9$ \\
\hline & $\mathrm{HCl}$ & $5.26 \pm 0.1$ & $0.49 \pm 0.2^{\mathrm{b}}$ & $10.14 \pm 0.0$ & $5.49 \pm 0.1$ \\
\hline & $\mathrm{F}$ & $0.23 \pm 0.1$ & $0.49 \pm 0.3^{b}$ & $7.12 \pm 3.9$ & $4.31 \pm 3.8$ \\
\hline & B & $10.56 \pm 0.2$ & $3.83 \pm 2.1$ & $6.04 \pm 2.7$ & $1.78 \pm 0.6^{\mathrm{a}}$ \\
\hline \multirow[t]{4}{*}{$\mathrm{C} 16: 0$} & $\mathrm{C}$ & $11.57 \pm 1.4$ & $21.37 \pm 1.1$ & $14.87 \pm 1.1$ & $11.01 \pm 2.0$ \\
\hline & $\mathrm{HCl}$ & $10.92 \pm 1.0$ & $16.27 \pm 2.2^{\mathrm{ab}}$ & $20.43 \pm 0.3$ & $11.80 \pm 1.4$ \\
\hline & $\mathrm{F}$ & $14.57 \pm 1.4$ & $21.11 \pm 13.11$ & $13.96 \pm 7.8$ & $11.58 \pm 4.2$ \\
\hline & $\mathrm{B}$ & $20.17 \pm 1.3$ & $23.08 \pm 2.5$ & $10.40 \pm 1.0^{\mathrm{c}}$ & $9.42 \pm 3.2$ \\
\hline \multirow[t]{4}{*}{ C16 : 1} & $\mathrm{C}$ & $6.62 \pm 1.5$ & $4.86 \pm 1.2$ & $7.88 \pm 2.3$ & $4.52 \pm 1.0$ \\
\hline & $\mathrm{HCl}$ & $6.03 \pm 0.3$ & $\operatorname{Tr}{ }^{* * *}$ & $\operatorname{Tr}$ & $\operatorname{Tr}$ \\
\hline & $F$ & $8.46 \pm 0.1$ & $0.03 \pm 0.0$ & $0.79 \pm 0.2$ & $\operatorname{Tr}$ \\
\hline & B & $5.64 \pm 0.9$ & $3.27 \pm 1.6$ & $0.94 \pm 0.3$ & $6.75 \pm 3.5$ \\
\hline \multirow[t]{4}{*}{ C18:0 } & C & $7.76 \pm 0.4$ & $9.29 \pm 0.4$ & $12.66 \pm 2.3$ & $6.57 \pm 1.3$ \\
\hline & $\mathrm{HCl}$ & $8.48 \pm 0.7$ & $1.23 \pm 0.1^{\mathrm{ab}}$ & $10.10 \pm 1.1$ & $5.90 \pm 0.6$ \\
\hline & $\mathrm{F}$ & $10.18 \pm 1.0$ & $2.18 \pm 1.1^{\mathrm{ab}}$ & $9.91 \pm 1.8$ & $8.38 \pm 4.4$ \\
\hline & $\mathrm{B}$ & $6.05 \pm 2.3$ & $7.06 \pm 1.3$ & $5.69 \pm 2.0^{\mathrm{acd}}$ & $5.09 \pm 1.4$ \\
\hline \multirow[t]{4}{*}{ C18: 1} & $\mathrm{C}$ & $10.90 \pm 2.2^{\mathrm{bcd}}$ & $28.98 \pm 5.5^{c}$ & $15.17 \pm 3.6$ & $33.89 \pm 1.1$ \\
\hline & $\mathrm{HCl}$ & $24.21 \pm 1.1$ & $42.15 \pm 7.9$ & $30.99 \pm 13.9$ & $32.28 \pm 9.9$ \\
\hline & $\mathrm{F}$ & $21.88 \pm 3.7$ & $32.33 \pm 2.3^{c}$ & $23.78 \pm 13.9$ & $26.63 \pm 9.8$ \\
\hline & B & $28.93 \pm 5.2$ & $24.39 \pm 2.1^{c}$ & $33.16 \pm 0.9$ & $28.72 \pm 3.4$ \\
\hline \multirow[t]{4}{*}{ C18: 2} & $\mathrm{C}$ & $36.59 \pm 5.5$ & $19.11 \pm 4.0^{\mathrm{bcd}}$ & $33.99 \pm 11.6$ & $10.45 \pm 0.6^{\mathrm{cd}}$ \\
\hline & $\mathrm{HCl}$ & $37.65 \pm 2.4$ & $34.94 \pm 2.5$ & $24.51 \pm 6.1$ & $26.55 \pm 2.8$ \\
\hline & $\mathrm{F}$ & $35.26 \pm 6.8$ & $37.18 \pm 10.4$ & $27.45 \pm 4.6$ & $31.31 \pm 2.7$ \\
\hline & B & $13.76 \pm 2.0^{\mathrm{abc}}$ & $28.79 \pm 8.4$ & $35.60 \pm 1.9$ & $12.76 \pm 3.9^{\mathrm{cd}}$ \\
\hline \multirow[t]{4}{*}{$\mathrm{C} 18: 3$} & $\mathrm{C}$ & $0.34 \pm 0.0$ & $0.66 \pm 0.0$ & $\mathrm{Tr}$ & $\operatorname{Tr}$ \\
\hline & $\mathrm{HCl}$ & $\operatorname{Tr}$ & $2.59 \pm 0.8$ & $\mathrm{Tr}$ & $\operatorname{Tr}$ \\
\hline & $\mathrm{F}$ & $0.03 \pm 0.0$ & $0.35 \pm 0.1^{\mathrm{d}}$ & $0.32 \pm 0.0$ & $0.02 \pm 0.0$ \\
\hline & B & $0.42 \pm 0.2$ & $1.65 \pm 1.0$ & $1.77 \pm 1.6$ & $0.09 \pm 0.0$ \\
\hline \multirow[t]{4}{*}{$\mathrm{C} 20: 0$} & C & $0.20 \pm 0.0$ & $0.94 \pm 0.0$ & $0.11 \pm 0.0$ & Tr. \\
\hline & $\mathrm{HCl}$ & $\operatorname{Tr}$ & $0.59 \pm 0.1$ & $1.13 \pm 0.2$ & $0.50 \pm 0.1$ \\
\hline & $\mathbf{F}$ & $0.03 \pm 0.0$ & Tr. & $0.71 \pm 0.2$ & $0.18 \pm 0.0$ \\
\hline & B & $0.32 \pm 0.0$ & $\operatorname{Tr}$ & $2.85 \pm 2.1$ & $0.92 \pm 0.4$ \\
\hline \multirow[t]{4}{*}{$\mathrm{C} 20: 4$} & $\mathrm{C}$ & $1.57 \pm 0.6$ & $4.11 \pm 0.3$ & $3.37 \pm 0.6$ & $23.64 \pm 6.9$ \\
\hline & $\mathrm{HCl}$ & $7.39 \pm 2.7$ & $1.73 \pm 0.4^{\mathrm{abd}}$ & $2.51 \pm 0.4$ & $15.00 \pm 5.0$ \\
\hline & $\mathrm{F}$ & $5.99 \pm 5.6$ & $4.94 \pm 0.5$ & $2.83 \pm 0.2$ & $14.64 \pm 5.2^{b}$ \\
\hline & $\mathrm{B}$ & $4.75 \pm 1.5$ & $4.16 \pm 1.9$ & $3.07 \pm 1.6$ & $31.66 \pm 1.8$ \\
\hline \multirow[t]{4}{*}{$\mathrm{C} 20: 5$} & $\mathrm{C}$ & $3.61 \pm 1.4$ & $1.76 \pm 0.9$ & $0.12 \pm 0.0$ & $1.06 \pm 1.2$ \\
\hline & $\mathrm{HCl}$ & $\operatorname{Tr}$ & $\mathrm{Tr}$ & $\operatorname{Tr}$ & $2.16 \pm 0.4$ \\
\hline & $F$ & $\operatorname{Tr}$ & $0.48 \pm 0.4$ & $10.62 \pm 4.3$ & $\operatorname{Tr}$ \\
\hline & $\mathrm{B}$ & $5.79 \pm 2.8$ & $2.28 \pm 0.4$ & $\operatorname{Tr}$ & $1.25 \pm 0.9$ \\
\hline \multirow[t]{4}{*}{ C22: 6} & C & $7.16 \pm 1.3$ & $2.56 \pm 0.1$ & $4.31 \pm 0.6$ & $1.44 \pm 1.0$ \\
\hline & $\mathrm{HCl}$ & $\operatorname{Tr}$ & $\operatorname{Tr}$ & $\mathrm{Tr}$ & Tr. \\
\hline & $F$ & $1.45 \pm 0.4^{\mathrm{a}}$ & $1.10 \pm 1.7$ & $1.42 \pm 0.2$ & $0.72 \pm 0.8$ \\
\hline & B & Tr. & $0.85 \pm 0.2^{\mathrm{a}}$ & $0.27 \pm 0.0$ & $0.12 \pm 0.0$ \\
\hline \multirow{2}{*}{$\begin{array}{l}\text { Unknown } \\
\text { and }\end{array}$} & $\mathrm{C}$ & $6.27 \pm 5.4$ & $1.84 \pm 1.9$ & $1.95 \pm 2.5$ & $2.08 \pm 2.1$ \\
\hline & $\mathrm{HCl}$ & $0.06 \pm 0.0$ & $0.01 \pm 0$ & $0.19 \pm 0.0$ & $0.32 \pm 0.0$ \\
\hline \multirow[t]{2}{*}{ Others } & $\mathrm{F}$ & $0.92 \pm 0.3$ & $\operatorname{Tr}$ & $1.09 \pm 0.2$ & $2.23 \pm 0.5$ \\
\hline & B & $3.51 \pm 0.0$ & $0.64 \pm 0.0$ & $0.21 \pm 0.0$ & $1.44 \pm 0.0$ \\
\hline
\end{tabular}

* Dietary group, $\mathrm{C}$ : Control, $\mathrm{HCl}:$ Glucosamine-HCl, F : Free glucosamine, B : Browning pigments products of glucosamine, ${ }^{* *}$ Values are the means $\pm S$. D., *** Trace

$a_{1} b_{1} c_{1} d_{1}=$ Significantly different from the corresponding control at $p<0.01$, BGA at $p<0.01, G A-$ $\mathrm{HCl}$ at $\mathrm{p}<0.01$, and $\mathrm{FGA}$ at $\mathrm{p}<0.01$, respectively 
Table 2 Composition of main fatty acids of liver lipid in the rats

$(w t \%)$

\begin{tabular}{|c|c|c|c|c|c|}
\hline $\begin{array}{l}\text { Fatty } \\
\text { acids }\end{array}$ & $D G^{*}$ & Sterol esters & Triacylglycerines & Free fatty acids & Compound lipids \\
\hline \multirow[t]{4}{*}{$\mathrm{C} 14: 0$} & $\mathrm{C}$ & $0.39 \pm 0.3^{* *}$ & $0.54 \pm 0.2$ & $2.23 \pm 1.0^{\mathrm{d}}$ & $1.02 \pm 0.9$ \\
\hline & $\mathrm{HCl}$ & $1.41 \pm 0.1$ & $0.30 \pm 0.0$ & $1.22 \pm 0.2$ & $2.16 \pm 0.2$ \\
\hline & $\mathrm{F}$ & $0.60 \pm 0.2$ & $0.35 \pm 0.1$ & $6.06 \pm 2.4$ & $4.64 \pm 1.7$ \\
\hline & B & $0.49 \pm 0.1$ & $0.54 \pm 0.1$ & $1.07 \pm 0.1$ & $1.24 \pm 0.9$ \\
\hline \multirow[t]{4}{*}{$\mathrm{C} 16: 0$} & $\mathrm{C}$ & $13.60 \pm 2.4$ & $31.30 \pm 4.1$ & $22.90 \pm 3.1^{c}$ & $18.60 \pm 2.7$ \\
\hline & $\mathrm{HCl}$ & $17.41 \pm 2.0$ & $31.83 \pm 2.6$ & $34.22 \pm 2.2$ & $27.78 \pm 4.4$ \\
\hline & $\mathrm{F}$ & $14.24 \pm 2.5$ & $34.05 \pm 0.4$ & $28.38 \pm 0.4$ & $13.83 \pm 0.4^{\mathrm{ac}}$ \\
\hline & $\mathrm{B}$ & $21.09 \pm 7.4$ & $28.96 \pm 6.3$ & $21.75 \pm 4.0^{c}$ & $15.04 \pm 4.2$ \\
\hline \multirow[t]{4}{*}{$\mathrm{C} 16: 1$} & $\mathrm{C}$ & $\operatorname{Tr}{ }^{* * *}$ & Tr. & Tr. & $1.40 \pm 0.3$ \\
\hline & $\mathrm{HCl}$ & $0.05 \pm 0.0$ & Tr. & $\operatorname{Tr}$ & $3.14 \pm 0.2$ \\
\hline & $\mathrm{F}$ & $0.14 \pm 0.0$ & $\mathrm{Tr}$. & Tr. & $3.66 \pm 0.8$ \\
\hline & B & $0.81 \pm 0.6$ & $\mathrm{Tr}$. & Tr. & $2.71 \pm 1.4$ \\
\hline \multirow[t]{4}{*}{$\mathrm{C} 18: 0$} & $\mathrm{C}$ & $12.16 \pm 1.4$ & Tr. & $14.89 \pm 3.3^{\mathrm{a}}$ & $14.40 \pm 1.6$ \\
\hline & $\mathrm{HCl}$ & $8.27 \pm 0.4$ & $2.37 \pm 0.1^{\mathrm{b}}$ & $7.45 \pm 0.1^{\mathrm{a}}$ & $8.00 \pm 0.5^{\mathrm{a}}$ \\
\hline & $\mathrm{F}$ & $5.89 \pm 1.6^{\mathrm{a}}$ & $2.29 \pm 0.2^{b}$ & $7.96 \pm 2.4^{\mathrm{a}}$ & $7.64 \pm 0.4^{\mathrm{a}}$ \\
\hline & B & $3.68 \pm 1.9^{a c}$ & $4.00 \pm 0.9$ & $7.27 \pm 0.6$ & $8.41 \pm 2.5^{\mathrm{a}}$ \\
\hline \multirow{4}{*}{$\mathrm{C} 18: 1$} & $\mathrm{C}$ & $44.38 \pm 2.7$ & $30.51 \pm 3.5^{b}$ & $28.63 \pm 4.4^{\mathrm{b}}$ & $36.00 \pm 5.1$ \\
\hline & $\mathrm{HCl}$ & $28.32 \pm 2.6^{\text {abd }}$ & $31.84 \pm 5.1^{b}$ & $22.17 \pm 3.6^{\mathrm{b}}$ & $20.62 \pm 4.1^{\mathrm{ab}}$ \\
\hline & $\mathrm{F}$ & $48.33 \pm 3.8$ & $29.33 \pm 1.2$ & $23.80 \pm 3.3$ & $30.70 \pm 7.4^{\mathrm{a}}$ \\
\hline & $\mathrm{B}$ & $44.97 \pm 4.3$ & $36.16 \pm 1.2$ & $36.73 \pm 2.2$ & $40.07 \pm 1.8$ \\
\hline \multirow[t]{4}{*}{$\mathrm{C} 18: 2$} & $\mathrm{C}$ & $19.10 \pm 2.1$ & $34.34 \pm 1.8$ & $12.98 \pm 1.6$ & $23.20 \pm 0.6$ \\
\hline & $\mathrm{HCl}$ & $26.38 \pm 3.0^{\mathrm{a}}$ & $29.29 \pm 3.0$ & $19.11 \pm 2.1$ & $28.68 \pm 4.0$ \\
\hline & $\mathrm{F}$ & $26.73 \pm 5.5^{a}$ & $27.89 \pm 1.3$ & $22.37 \pm 4.2^{\mathrm{a}}$ & $20.93 \pm 0.7$ \\
\hline & $\mathrm{B}$ & $22.97 \pm 1.6$ & $27.47 \pm 5.3$ & $22.29 \pm 3.0^{\mathrm{a}}$ & $18.54 \pm 3.0^{c}$ \\
\hline \multirow[t]{4}{*}{$\mathrm{C} 18: 3$} & $\mathrm{C}$ & Tr. & Tr. & Tr. & $0.12 \pm 0.0$ \\
\hline & $\mathrm{HCl}$ & $0.11 \pm 0.0$ & Tr. & $0.25 \pm 0.1$ & $0.92 \pm 0.2$ \\
\hline & $\mathrm{F}$ & $0.24 \pm 0.1$ & $0.18 \pm 0.0$ & Tr. & $0.43 \pm 0.1$ \\
\hline & B & $0.10 \pm 0.0$ & $0.33 \pm 0.0$ & $0.25 \pm 0.0$ & $0.51 \pm 0.1$ \\
\hline \multirow{4}{*}{$\mathrm{C} 20: 0$} & $\mathrm{C}$ & $0.04 \pm 0.0$ & Tr. & $\mathrm{Tr}$ & Tr. \\
\hline & $\mathrm{HCl}$ & $1.82 \pm 0.1$ & $0.36 \pm 0.0$ & $1.11 \pm 0.2$ & Tr. \\
\hline & F & Tr. & $0.95 \pm 0.1$ & $0.17 \pm 0.0$ & $0.87 \pm 0.1$ \\
\hline & B & $0.47 \pm 0.1$ & $0.46 \pm 0.0$ & $0.36 \pm 0.1$ & $0.14 \pm 0.0$ \\
\hline \multirow[t]{4}{*}{$\mathrm{C} 20: 4$} & $\mathrm{C}$ & $10.13 \pm 2.3$ & $3.31 \pm 1.3$ & $4.29 \pm 2.0$ & $2.88 \pm 0.3$ \\
\hline & $\mathrm{HCl}$ & $9.93 \pm 1.6$ & $3.82 \pm 0.3$ & $9.31 \pm 1.1$ & $2.12 \pm 0.2$ \\
\hline & $\mathrm{F}$ & $3.31 \pm 0.5^{\mathrm{ac}}$ & $3.71 \pm 0.5$ & $4.65 \pm 3.7$ & $3.46 \pm 0.7$ \\
\hline & $\mathrm{B}$ & $4.36 \pm 1.3^{\text {ac }}$ & $3.01 \pm 0.1$ & $4.02 \pm 0.3$ & $1.86 \pm 0.8$ \\
\hline \multirow[t]{4}{*}{$\mathrm{C} 20: 5$} & $\mathrm{C}$ & $0.19 \pm 0.0$ & Tr. & $11.93 \pm 2.9$ & $1.12 \pm 0.5^{\mathrm{c}}$ \\
\hline & $\mathrm{HCl}$ & $6.13 \pm 2.0$ & Tr. & $1.98 \pm 1.7$ & $5.97 \pm 1.9^{\mathrm{c}}$ \\
\hline & $\mathrm{F}$ & $0.50 \pm 0.1$ & $\operatorname{Tr}$. & $4.97 \pm 1.7$ & $11.48 \pm 6.2$ \\
\hline & $\mathrm{B}$ & $0.29 \pm 0.1$ & Tr. & $1.79 \pm 0.4$ & $4.74 \pm 2.6^{c}$ \\
\hline \multirow{4}{*}{$\mathrm{C} 22: 6$} & $\mathrm{C}$ & Tr. & $\operatorname{Tr}$ & $\operatorname{Tr}$ & $\operatorname{Tr}$ \\
\hline & $\mathrm{HCl}$ & Tr. & Tr. & $2.72 \pm 0.3$ & Tr. \\
\hline & $\mathrm{F}$ & $\operatorname{Tr}$ & $0.66 \pm 0.2$ & $1.30 \pm 0.3^{b}$ & $0.56 \pm 0.2$ \\
\hline & $\mathrm{B}$ & $0.76 \pm 0.5$ & $\operatorname{Tr}$ & $3.12 \pm 0.4$ & $5.47 \pm 6.4$ \\
\hline \multirow{4}{*}{$\begin{array}{l}\text { Unknown } \\
\text { and } \\
\text { Others }\end{array}$} & $\mathrm{C}$ & $0.01 \pm 0.0$ & $\operatorname{Tr}$ & $2.15 \pm 0.5$ & $1.26 \pm$ \\
\hline & $\mathrm{HCl}$ & $0.02 \pm 0.0$ & Tr. & $0.46 \pm 0.2$ & $0.62 \pm$ \\
\hline & $\mathrm{F}$ & Tr. & $0.59 \pm 0.0$ & $0.52 \pm 0.0$ & $1.80 \pm$ \\
\hline & $\mathrm{B}$ & $0.77 \pm 0.5$ & $\operatorname{Tr}$ & $1.35 \pm 0.2$ & $1.27 \pm$ \\
\hline
\end{tabular}

* Dietary group, C : Control, $\mathrm{HCl}:$ Glucosamine-HCl, F : Free glucosamine, B : Browning pigments products of glucosamine, ${ }^{* *}$ Values are the means \pm S. D., $* * *$ Trace

$a, b, c, d=$ Significantly different from the corresponding control at $p<0.01$, BGA at $p<0.01$, GA$\mathrm{HCl}$ at $\mathrm{p}<0.01$, and FGA at $\mathrm{p}<0.01$, respectively 


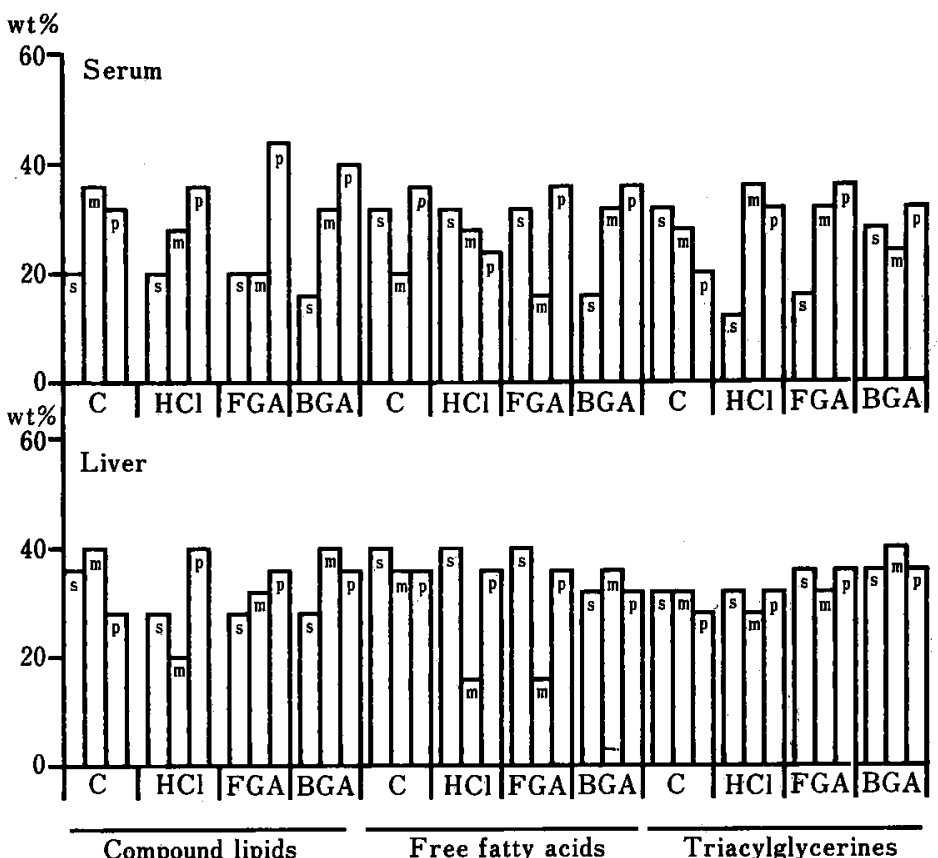

Fig. 1 Changes of saturated, monoenoic and polyenoic acids of compound lipids, free fatty acids and triacylglycerines in serum and liver total lipids of rats

Saturated acids : s, Monoenoic acids : $m$, Polyenoic acids : $p$

ポリエン酸量は, FGA $>$ Control $>$ BGA $>$ GA-HCl の順であった.

さらに，CL，TG，FFAのポリエン酸量はFGA， BGA が高值で推移し，逆に，CL, FFA の FGA の モノエン酸量や TG の BGA のモノェン酸量が低い值 を示した．このことから，FGA，BGA にはポリェン 酸を高く保つ作用があるものと推察された。 また，ポリ エン酸量は，FFA，TG で変動が大きく，CL で高い值 を示したが，その減少がどの脂質で影響を示すか明らか にすることは出来なかった。

一方，肝㵴中の各脂質の脂肪酸は，17～20 種類を認 めた。これらの主要脂肪酸は，C $16: 0, C 18: 0, \mathrm{C}$ $18: 1, \mathrm{C} 18: 2, \mathrm{C} 20: 4$ の 5 種であり 50 〜0\%を占め た. また, CL, TG, FFAのモノェン酸量,ポリェン 酸量については CL, FFA の GA-HCl と FFA の FGA のモノェン酸量で低值を示した以外，各群間で明 らかな差が認められなかった。すなわち，Fig. 1 に示 す $\mathrm{CL}$ のノエン酸量は, BAG $>$ Control $>$ FGA> $\mathrm{GA}-\mathrm{HCl}$ の順であり, ポリエン酸量では, $\mathrm{GA}-\mathrm{HCl}>$
BGA > FGA > Control の順であった. TGのモ/エ ン酸量は, $\mathrm{BGA}>\mathrm{FGA}>\mathrm{Control}>\mathrm{GA}-\mathrm{HCl}$ の順で あり，ポリエン酸量では, $\mathrm{BGA}>\mathrm{FGA}>\mathrm{GA}-\mathrm{HCl}>$ Control の順であった，FFAのモノェン酸量は， $\mathrm{BGA}>\mathrm{Control}>\mathrm{FGA}>\mathrm{GA}-\mathrm{HCl}$ の順であり, ポリ エン酸量では，FGA> GA- $\mathrm{HCl}>$ Control $>$ BGA の 順であった．FFA，TGのポリエン酸量は比較的に高 值で推移したが，FFA，CLのモ/エン酸量や CLの ポリエン酸量では変動の幅が大きかった.

ところで, 肝臟の複合脂質中のアラキドン酸や血獎中 TG のリノール酸は割合が抗酸化剂の種類によって全く 異なること”ヤメイラード反応生成物は生体内です抗酸

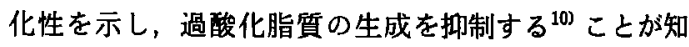
られている. 強い抗酸化性が確認された $\mathrm{BGA}^{\text {() }}$ は血清 や肝蔵 TL の脂肪酸レベルでの作用は認められなかっ たが，血清や肝蔵の構成脂質及び脂肪酸の中で，特に影 響があると考えられる CL で，ポリエン酸量の変動が 大きかった．このことから，FGAゃ BGA がポリエ ン酸の代謝に少なからず影響を与えているものと考えら 
れた。また，前報5)で降コレステロール作用を示した， FGA と BGA ではポリエン酸量が比較的に高值で推 移したことからポリエン酸の変動がコレステロールの低 下に結びついているものと考えられる。

\section{3. 要約}

遊離 Glucosamine 及びその褐変物質を投与したラ ットの血清及び肝缄脂質を TLCで分画した後，それぞ れの脂質の脂肪酸組成を測定し，以下の結果を得た.

1. TLC に上る脂質分画では，血清及び肝脿で 7 種 の画分を諗めた。

2. 血清及び肝葴の CL, FFA，TG，SE の゙主要脂肪 酸は，C $16: 0$, C $18: 0$, C $18: 1$, C $18: 2$, C $20: 4$ で あった.

3. FGA は血清の各脂質のポリエン酸の減少を抑制 したが，BGA では，血清及び肝葴の各脂質において脂 肪酸の変動に明らかな傾向を示さなかった。
終わりに，本研究の一部は日本食品工業学会第 36 回 大会に於いて発表致しました。

$$
\text { 文献 }
$$

1）小柳津周 : 栄養学雑誌，44，307 (1986).

2）小柳津周 : 栄養学雑誌, 46, 35 (1988).

3）小柳津周 : 日食工誌, 35, 771 (1988).

4）小柳津周 : 日食工誌， 35，40（1988）.

5）小柳津周 - 田村 弘：日食工誌，36，873 (1989).

6）和田正太・营野道弘：九大農学芸誌, 26, 505 (1972).

7）山田 実・林 賢治：日水誌，41，1143（1975).

8）安田正秀 - 藤田 直 - 水谷泰久: 薬学雑誌, 285 , 99 (1979).

9）長 修司・菅野道広 : 農化, 49, 27 (1975).

10）グェエン ウァン チェン:農化, 61, 979 (1987). 